\title{
Fatty acid composition and antioxidant capacity in linseed grown as forage in Mediterranean environment
}

\author{
Leonardo Sulas, Giovanni Antonio Re, Federico Sanna, Simonetta Bullitta, Giovanna Piluzza \\ National Research Council, Institute for the Animal Production System in Mediterranean Environment \\ (CNR-ISPAAM), Sassari, Italy
}

\begin{abstract}
This research was aimed at studying the bromatological traits, fatty acid profile, bioactive compounds, and antioxidant capacity in linseed (Linum usitatissimum L.) shoots harvested at six codified morphological stages. Quality traits were significantly related to cumulated growing degree days from seedling emergence to senescence. The crude protein and ash contents exhibited a gradual decrease and were negatively correlated with morphological stages, whereas cell wall components such as neutral, acid detergent fibers and lignin (NDF, ADF, and ADL) and ether extract (EE) showed a positive correlation. Both ABTS [(2,2'-azinobis (3ethylbenzothiazoline-6-sulphonic acid) diammonium salt] and DPPH (1,1-diphenyl-2-picrylhydrazyl) assays indicated a reduction in antioxidant capacities from stem extension to senescence, from 16 to 7.1 , and 19 to $7 \mathrm{mmol}$ TEAC/100g DW, for ABTS and $\mathrm{DPPH}$, respectively. Significant linear correlation among the antioxidant activity, phenolics, NDF, ADF, ADL, and EE were found showed usually. Total phenolic (9.6-26.4 $\mathrm{g} \mathrm{GAE} \mathrm{kg}^{-1}$ ) and total flavonoid (5.2-16.7 $\mathrm{g} \mathrm{CE} \mathrm{kg}^{-1}$ ) contents were negatively related with morphological stages. The morphological stage was significantly correlated with oil content, although individual fatty acid content did not. Research gives new insights into the evolu-
\end{abstract}

Correspondence: Giovanni Antonio Re, National Research Council, Institute for the Animal Production System in Mediterranean Environment (CNR-ISPAAM), Traversa La Crucca 3, Località Baldinca, 07100 Sassari, Italy.

E-mail: giovanniantonio.re@cnr.it

Key words: Linum usitatissimum; fodder; morphological stages; polyphenols; $\alpha$-linolenic acid; growing degree-days.

Acknowledgements: the authors wish to acknowledge the financial support of Fondazione Banco di Sardegna (Sassari) and the technical help of Mr. Salvatore Nieddu, Mr. Daniele Nieddu, Mr. Daniele Dettori, Mr. Anton Pietro Stangoni, Dr. Maddalena Spezzigu, Ms. Maddalena Sassu and Mr. Piero Saba.

Received for publication: 11 June 2018.

Revision received: 8 January 2019.

Accepted for publication: 8 January 2019.

CCopyright L. Sulas et al., 2019

Licensee PAGEPress, Italy

Italian Journal of Agronomy 2019; 14:1291

doi:10.4081/ija.2019.1291

This article is distributed under the terms of the Creative Commons Attribution Noncommercial License (by-nc 4.0) which permits any noncommercial use, distribution, and reproduction in any medium, provided the original author(s) and source are credited. tion of chemical composition of linseed shoot. Remarkable variations in quality traits, fatty acid contents, bioactive compounds, and antioxidant capacity evidence the possibility to use green linseed in animals' diet, also suggesting the exploitation of linseed plant as forage source.

\section{Introduction}

Linum usitatissimum L. (linseed, also called flax or flaxseed), an annual herbaceous species belonging to the Linaceae family, is originating from the Middle East and has been cultivated in Mesopotamia since ancient times. Its use has been documented as far back as $3000 \mathrm{BC}$ with a long history of food, medicine, and textile fiber. Linseed was subsequently introduced to several regions including Europe (Zuk et al., 2015).

Linseed is generally regarded as a dual-purpose crop due to its main products, namely fiber and seed (Jankauskiené et al., 2015; Zuk et al., 2015), and it is still widely grown for oil, fiber, and food. Recently, it is emerging as one of the key sources of phytochemicals in functional foods (Kajla et al., 2015). In fact, linseed is rich in $\alpha$-linolenic acid and lignans, is an essential fount of highquality protein and soluble fiber and has also considerable potential as a source of phenolic compounds (Oomah, 2001). As a result of divergent plant selection (Diederihsen and Ulrich, 2009), linseed for oil grows up to $40-60 \mathrm{~cm}$ tall, whereas fiber linseed plant grows up to $80-120 \mathrm{~cm}$ and is less branched. Since many years ago, the fiber has been converted to yarn, which served as a major source to manufacture textiles for table or bed covering and clothing, whereas seeds have been pressed to extract edible oil (Zuk et al., 2015). Furthermore, the same authors reported that total fat content in linseed plant was $35-46 \%$, total protein accounted for $18-25 \%$ and carbohydrate constituted $23-30 \%$. Linoleic acid content was in the range 16 to $75 \%$ and $\alpha$-linolenic acid varied from 1.7 to $59 \%$.

Cloutier et al. (2011) and Zuk et al. (2015) detailed that the average content of linseed oil is $35-50 \%$ of the seed weight. In linseed oil, the most frequently found fatty acids are palmitic $(6 \%)$, stearic $(2.5 \%)$, oleic $(19 \%)$, linoleic $(13 \%)$ and $\alpha$-linolenic acid (55\%). Moreover, the oil content and fatty acid composition often change due to crop adaptation to local environmental conditions (Cloutier et al., 2011). Duguid (2009) and Fofana et al. (2006) reported that the seed oil content varied up to $15 \%$, and the percentage of $\alpha$-linolenic acid might increase (ca. $5 \%$ ) in cooler environments, respectively. Linoleic acid (LA) and $\alpha$-linolenic acid (ALA) are the main fatty acids that are mostly modified by anaerobic bacteria in the rumen via biohydrogenation process aimed to produce saturated fatty acids (Chilliard et al., 2000). LA, ALA, and vaccenic acid (VA) found in dairy products have been shown to possess peculiar nutritional properties as modifiers of cardiovascular risk (Pintus et al., 2013). Moreover, pasture and lipid 
supplementation of the ruminant's diet have been reported to be reliable dietary strategies in ruminant nutrition, in order to increase milk content of $n-3$ fatty acids, conjugated linoleic acid (CLA) and VA (Nudda et al., 2006; Mele 2009; Mele et al., 2011; Pintus et al., 2013). Conversely, Cabiddu et al. (2017) reported that supplementation of grazing ewes with oilseeds is proven effective to increase the level of CLA, polyunsaturated fatty acid (PUFA) and monounsaturated fatty acid in milk, compared to unsupplemented grazing; they also evidenced that oilseed can increase putatively noxious trans fatty acid in respect to the unsupplemented herbage-fed treatment. According to Correddu et al. (2015), in the last few decades, a lot of attention has been directed to the content of healthy fatty acid (FA), especially polyunsaturated fatty acids belonging to the n-3 (PUFA n-3), such as LA and ALA in ruminant milk and dairy productions. Moreover, many studies have demonstrated that diet composition and rumen microbial biohydrogenation strongly influence the fatty acid profile of milk and dairy products (Lourenço et al., 2010). Sejian et al. (2010) reported that adding linseed seed to high-quality forage in livestock diet could be an effective mean for reducing $\mathrm{CH}_{4}$ gas emission.

Nowadays, a novel aspect concerning the comprehensive utilisation of linseed seeds to produce food additives or suspplements with high nutritional value, attracts increasing interest (Wang et al., 2017). Linseed meal and straw are feed to livestock, but while linseed meal is an excellent protein source (about $350 \mathrm{~g} \mathrm{~kg}^{-1}$ ) linseed straw, even if of good quality, has about the same feed value of oat (Avena sativa L.) or barley (Hordeum vulgare L.) straw (Peiretti and Meineri, 2008). Nevertheless, linseed straw can be used safely as the only source of roughage for cattle (Peiretti and Meineri, 2008). Green linseed is nutritionally comparable to canola (Brassica napus L.) hay (Feist et al., 2007).

Health benefits of linseed can be credited mainly to its abundance in biologically active components (Russo and Reggiani, 2015). In particular, phenolic compounds (phenolic acid, flavonoids phenilpropanoids, and tannins) are excellent in preventing the excess of free radicals and avoiding their pathological effects (Kasote, 2013; Russo and Reggiani, 2015). Polyphenols are among the most significant compounds related to the antioxidant properties of plants materials. In plants, phenols play an important role in protection against photo-oxidation and disease resistance (Pandey and Rizvy 2009; Mojzer et al., 2016). Flavonoids have also been shown to act as scavengers of various oxidising species [i.e. superoxide $\left(\mathrm{O}_{2}^{-}\right)$, hydroxyl radicals, and peroxy radicals], and they may also act as quenchers of single oxygen (Harborne and Williams, 2000; Trem and Šmejkal, 2016). Recently, linseed have been incorporated as seed into food or feed with other nutraceuticals or ingredients to improve their quality (Nudda et al., 2006; Mele et al., 2011; Dong et al., 2015; de Moura et al., 2016; Wang et al., 2017).

Several authors found that the content of phenolics varies with the growth stage of plants such as birdsfoot trefoil (Lotus corniculatus L.), chicory (Chicorium intybus L.) sulla (Hedysarum coronarium L.), sainfoin (Onobrychis viciifolia Scop.), milk thistle (Silybum marianum (L.) Gaertn.), and garland (Chrysanthemum coronarium L.) (Häring et al., 2007; Piluzza and Bullitta 2010; Re et al., 2013; Piluzza et al., 2014a; Sulas et al., 2016; Sulas et al., 2017).

Peiretti and Maineri (2008) investigated the effect of maturity stage on FA profile in linseed and found that it is closely connected to plant development and that quality of the crop decreased from the first to the last morphological stage. The FA profile trend in the plant during growth is generally different from that of the corresponding seed oil, as reported for some herbages as borrago
(Borrago officinalis L.), galega (Galega officinalis L.), false flax (Camelina sativa L.), (Peiretti et al., 2004; Peiretti and Gai, 2006; Peiretti and Meineri, 2006). Linseed supplementation (as oil or seed) is a reliable feeding strategy to enhance unsaturated fatty acid in milk fat from cattle, sheep and goat (Chilliard et al., 2007; Mele et al., 2011; Santurino et al., 2017). Although several studies have reported its use as seed for feeding, the quality aspects of linseed shoots (aerial biomass) are little investigated so far. This research aimed at investigating the evolution of quality traits, fatty acid content, bioactive compounds (total polyphenolics, non-tannic phenolics, tannic phenolics, flavonoids, condensed tannins) and antioxidant capacity in linseed shoots harvested at six different codified morphological stages.

\section{Materials and methods}

The research was carried out at the experimental field of Leccari, Sassari (4045'12'N, 8'25'17'E; 27 m a.s.1.), in Sardinia (Italy), from 2013 to 2014 . The climate of the area is typically Mediterranean with mild winter, characterised by a long-term average annual rainfall of $554 \mathrm{~mm}$ mainly distributed in autumn and winter, and a mean annual air temperature of $16.2^{\circ} \mathrm{C}$. Daily maximum and minimum air temperatures and rainfall events were monitored by a weather station at the experimental site. From September 2013 to August 2014 total rainfall reached $718 \mathrm{~mm}$, concentrated in winter and spring exceeding climate means by $29 \%$. Mean temperatures never dropped below the average monthly value of $7^{\circ} \mathrm{C}$ (February 2013) and did not differ from long-term values. The soil at the experimental site has been classified as a Eutric, Calcaric and Mollic Fluvisol (FAO, 2006); it is sandy-clayloam, alkaline with a scarce average nitrogen content $(0.09 \%)$ and adequate contents of phosphorous (20.33 ppm), organic matter $(1.46 \%)$ and organic carbon $(0.85 \%)$.

In autumn 2013, plots (each sized about $25 \mathrm{~m}^{2}$ ) of the oilseed variety, Natural, were sown at a seeding rate of $50 \mathrm{~kg} \mathrm{ha}^{-1}$ corresponding to 450 plants per $\mathrm{m}^{-2}$, under a randomised block with 3 replicates. Fertilisation of $40 \mathrm{~kg} \mathrm{ha}^{-1}$ of $\mathrm{N}$ and $100 \mathrm{~kg} \mathrm{ha}^{-1}$ of $\mathrm{P}_{2} \mathrm{O}_{5}$, was applied at sowing. No irrigation or herbicides were applied.

The main morphological stages of linseed (Table 1), from stem extension (stage 3) to senescence (stage 9) were identified according to a BBCH scale (Smith and Froment, 1998) by adopting on a sample of 50 stems the average stage weight method (Borreani et al., 1999). Accumulated growing degree days (GDD) were calculated by summing the daily degree values $\left({ }^{\circ} \mathrm{C}\right)$ obtained subtracting the average temperature with the base temperature, which is $5^{\circ} \mathrm{C}$ for linseed (Fontana et al., 1998; Mirshekari et al., 2012).

At each morphological stage, representative aerial biomass (shoots) samples from $0.5 \mathrm{~m}^{2}$ per plot were cut at $5 \mathrm{~cm}$ above ground level. Fresh shoots were weighted and then oven-dried at $60^{\circ} \mathrm{C}$ until constant weight, and dry matter (DM) content and yield were calculated. Dried sub-samples of shoots were ground finely enough to pass through a $1 \mathrm{~mm}$ mesh before chemical determinations. Total $\mathrm{N}$ was determined by using a Kjeldahl method (AOAC Official Method 991.20) and crude protein (CP) was calculated by multiplying the $\mathrm{N}$ content by 6.25. Neutral, acid detergent fibers and lignin (NDF, ADF, and ADL), were determined according to Van Soest (1994) procedure and ether extract using Soxhlet extraction (AOAC official method 942.05).

Total digestible nutrients (TDN), digestible dry matter (DDM), dry matter intake (DMI), relative feed value (RFV) and net energy for lactation $\left(\mathrm{NE}_{\mathrm{l}}\right)$ were estimated according to the following equa- 
tions adapted from Lithourgidis et al. (2006) and Sadeghpour et al. (2014):

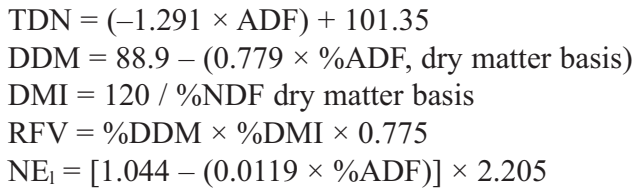

Additional fresh shoot subsamples were kept on ice at harvest, freeze-dried and ground to a fine powder for the analysis of secondary metabolites. The powdered material was then used for extract preparations as reported by Piluzza et al. (2014b). Total phenolics (TotP), non tannic phenolics (NTP) and tannic phenolics (TP) were determined using the Folin-Ciocalteau reagent according to Singleton and Rossi (1965), with some modifications (Piluzza et al., 2014b). Results were expressed as g gallic acid equivalent $\mathrm{kg}^{-1}$ dry weight of plant material (g GAE kg-1 DW). The butanol assay of Porter et al. (1986) was adapted (Piluzza and Bullitta, 2010) for quantification of extractable condensed tannin content from samples, expressed as $\mathrm{g}$ delphinidin equivalent $\mathrm{kg}^{-1}$ dry matter (g DE kg-1 DM). Total flavonoids (TotF) were quantified by colorimetric assay with the $\mathrm{AlCl}_{3}$ method (Kim et al., 2003). Catechin was used as a standard and the flavonoid content was expressed as $\mathrm{g}$ catechin equivalent $\mathrm{kg}^{-1}$ dry weight of plant material (g CE kg-1 DW).

Antioxidant capacity was determined by means of improved ABTS [2,2'-azinobis (3-ethylbenzothiazoline-6-sulphonic acid) diammonium salt] and DPPH (1,1-diphenyl-2-picrylhydrazyl) assays with some modifications (Surveswaran et al., 2007; Piluzza and Bullitta, 2011). Trolox, a water-soluble analogue of vitamin E was used as the reference standard. The results were expressed in terms of Trolox equivalent antioxidant capacity (TEAC), as mmol Trolox equivalents per $100 \mathrm{~g}$ dry weight of plant material ( $\mathrm{mmol}$ TEAC/100 g DW). Fatty acid compositions were determined in an external laboratory (AGRI-BIO-ECO, Pomezia, Rome, according to Pamioli 05 method, 2011).

\section{Statistical analysis}

Data were analysed using Statgraphics Centurion XVI version (StatPoint Technologies Inc., 2009). The regression analysis between polyphenols and antioxidant capacity, and between antioxidant capacity (ABTS, DPPH), total phenolics, non-tannic phenolics, tannic phenolics, flavonoids and quality values were processed using Microsoft Excel 2016. Homogeneity test of variance and arcsin transformation of percentages relative to data were performed.

\section{Results and discussion}

About $1790 \mathrm{GDD}{ }^{\circ} \mathrm{C}$ were required from seedling emergence to stem senescence of linseed and morphological stages were significantly related to GDD, $\left(\mathrm{R}^{2}=97 \% ; \mathrm{P}<0.0003\right.$; Figure 1). Mirshekari et al. (2012), found a very close value of 1799 GDD, considering the same base temperature $\left(5^{\circ} \mathrm{C}\right)$ in Iran. Zhang et al. (2014) and Miller et al. (2001) reported similar GDD ${ }^{\circ} \mathrm{C}$ data (1603-1801) and 1702, in Canada and Montana, respectively, even if the base temperature was $0^{\circ} \mathrm{C}$. Shoot dry matter yield (Figure 2) was controlled by GDD accumulation ranging from $0.4 \mathrm{t} \mathrm{ha}^{-1}$ at stem extension (stage 3) to $6.8 \mathrm{t} \mathrm{ha}^{-1}$ at stem senescence (Stage 9). Quality traits were significantly GDD related, in agreement with
Mirshekari et al. (2012) findings. According to Singh et al. (2013) and Soto-Cerda et al. (2014), genotype and environmental conditions could significantly affect linseed properties. The CP and ash content showed a gradual decrease whereas cell walls content (fiber fractions) and ether extract increased (Figure 3). For both quality parameter, correlation analysis exhibited a significant negatively association with morphological stages, $\mathrm{R}^{2}=0.88(\mathrm{P}<0.007$ and $\mathrm{P}<0.002)$. CP content decreased from 150 to 90 ( $\left.\mathrm{g} \mathrm{kg}^{-1} \mathrm{DM}\right)$ at stage 3 (stem extension) and stage 8 (ripening), respectively. In accordance with other authors (Bhatty and Cherdkiatgumchai, 1990; Saastamoinen et al., 2013; Tavarini et al., 2016), shoot CP content was negatively correlated $\left(\mathrm{R}^{2}=0.73 \quad \mathrm{P} \leq 0.02\right.$, data not shown) to its oil content, confirming that higher oil content corresponds to a lower $\mathrm{CP}$ concentration. Green linseed plant can potentially contain $80-180 \mathrm{~g} \mathrm{~kg}^{-1}$ of crude protein and $400-650 \mathrm{~g} \mathrm{~kg}^{-1}$ of total digestible nutrients and in the early stages of growth (prior capsule formation) and may be very nutritious, whereas in the later stages it may be very fibrous to be of practical use (Peiretti and Meineri, 2008). Cell wall components showed a positive correla-

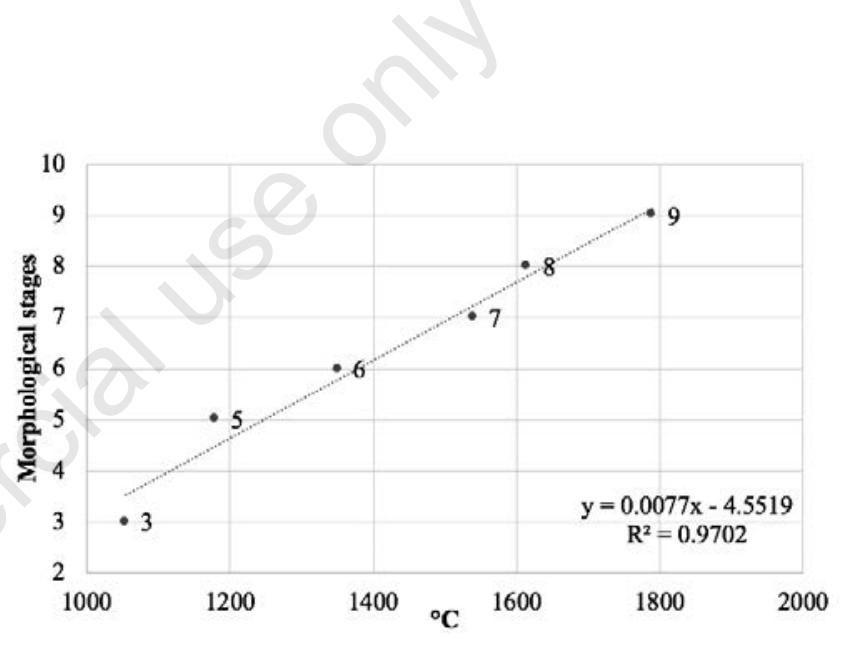

Figure 1. Linseed morphological stages in relation to growing degree days. Stages: 3: stem extension; 5: inflorescence emergence (main shoot); 6: flowering and capsule formation (whole plant); 7: development of seed and capsule; 8: capsule and seed ripening; 9: stem senescence.

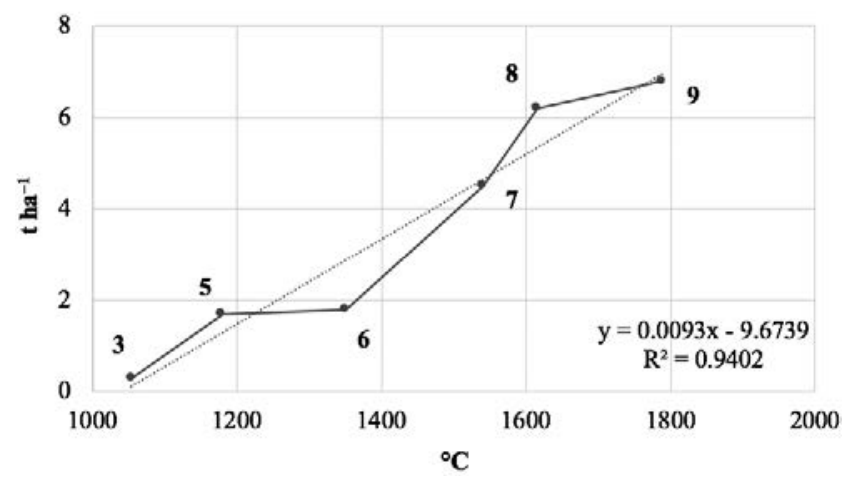

Figure 2. Shoot dry matter yield ( $\left.\mathrm{t} \mathrm{ha}^{-1} \mathrm{DM}\right)$ at six morphological stages across growing degree days. Stages: 3: stem extension; 5: inflorescence emergence (main shoot); 6: flowering and capsule formation (whole plant); 7: development of seed and capsule; 8: capsule and seed ripening; 9: stem senescence. 
tion with morphological stages; $\mathrm{R}^{2}$ were $0.90(\mathrm{P}<0.003), 0.84$ $(\mathrm{P}<0.015)$ and $0.84(\mathrm{P}<0.03)$ for NDF, ADF and ADL, respectively. In addition, ether extract concentration was positively correlated with morphological stages $\left(\mathrm{R}^{2}=0.81 \mathrm{P}<0.02\right)$. On later stages, (seeds formation) changes in cell wall components and ether extract concentration occurred, resulting in increases of NDF, ADF, lignin, and ether extract. The lowest NDF, ADF and fat contents (Figure 3B, C, and F) were found at the same stage (stage 3 stem extension), but later for ADL (stage 5 - inflorescence emergence (main stem) (Figure 3D). Levels of NDF, ADF and ADL were 480,330 and $90\left(\mathrm{~g} \mathrm{~kg}^{-1} \mathrm{DM}\right)$ at early stages, while they increased to 650,460 and $170\left(\mathrm{~g} \mathrm{~kg}^{-1} \mathrm{DM}\right)$ at seed ripening, confirming the fibrous characteristics of linseed shoot. Ash and ether extract ranged from 50.9 to $130 \mathrm{~g} \mathrm{~kg}^{-1} \mathrm{DM}$ and from 30 to $170 \mathrm{~g}$ $\mathrm{kg}^{-1} \mathrm{DM}$, respectively. Peiretti and Meineri (2008) found a similar value and trend for quality traits in vegetative linseed sown at springtime in North Italy; only ash and ether extract were higher in the present research. According to them, the quality of the crop decreased from the first to the last morphological stage, mainly with a digestibility reduction across the growing season.

As a general trend, TDN, DMI, DDM, RFV and $\mathrm{NE}_{1}$ values, showed a significant linear correlation with morphological stages (Table 1). The TDN refers to the available nutrients related to the ADF concentration and, as expected, TDN declines when ADF concentration increases, which mean that forage reduces its quality. TDN varied from 593 to $417 \mathrm{~g} \mathrm{~kg}^{-1} \mathrm{DM}$ at stage 3 (stem extension) and stage 9 (stem senescence), respectively, when ADF was $44 \%$. Usually, DMI is negatively correlated with NDF and this trend was also confirmed in linseed, DMI ranging from 18.4 to $25.2 \mathrm{~g} \mathrm{~kg}^{-1}$ DM. RFV exceeded the 151 value, which is indicative of prime forage (Horrocks and Vallentine, 1999) only at stage 3.

\section{A) Crude protein}

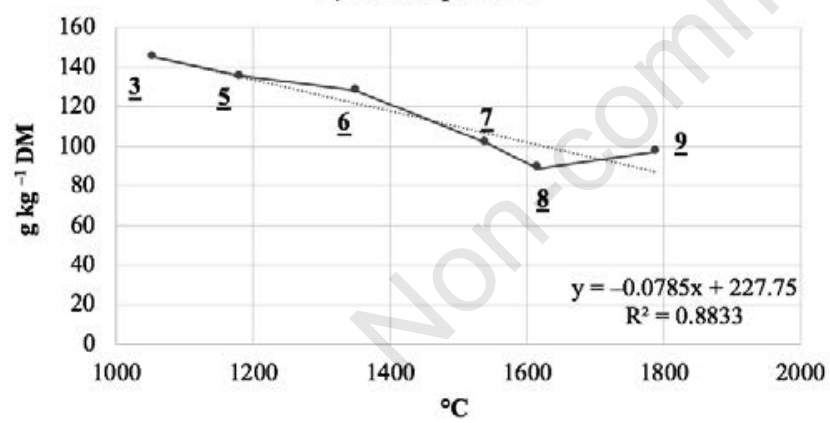

B) Neutral detergent fiber

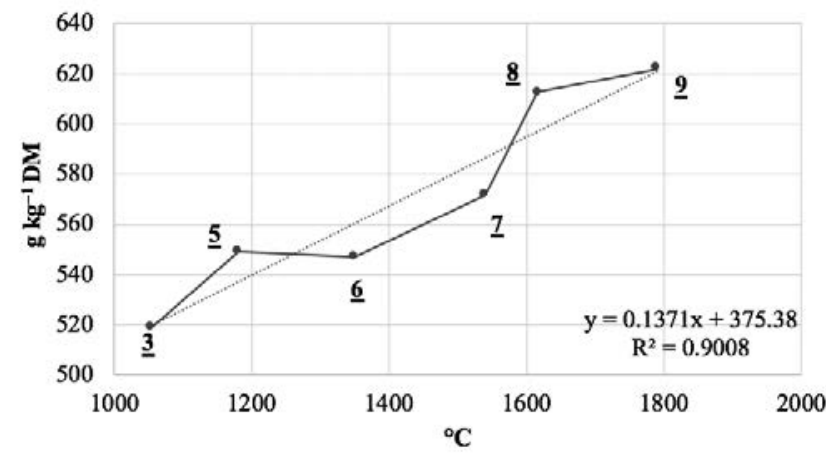

After stage 6 (flowering and capsule formation) when RFV was about 150 , it drastically decreased. A similar trend was observed for $\mathrm{NE}_{\mathrm{l}}$, that decreased from 1.45 (stage 3) to $1.09 \mathrm{Mcal} \mathrm{kg}^{-1}$ (stage 9). Phenolics are the secondary metabolites in plants involved in reproduction and physiology (Liu, 2007) and have been suggested to be responsible for antioxidant activity in many fruits, vegetables, and grains. Flavonoids are a class of phenolic compounds, involved in many biological processes, such as coloring in flowers

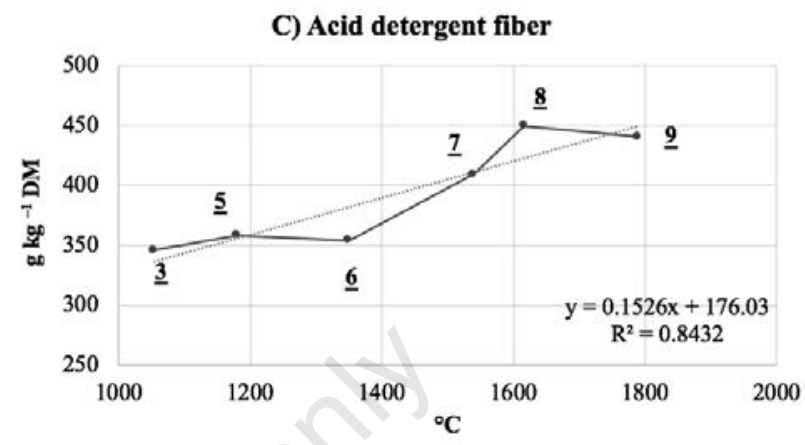

D) Acid detergent lignin

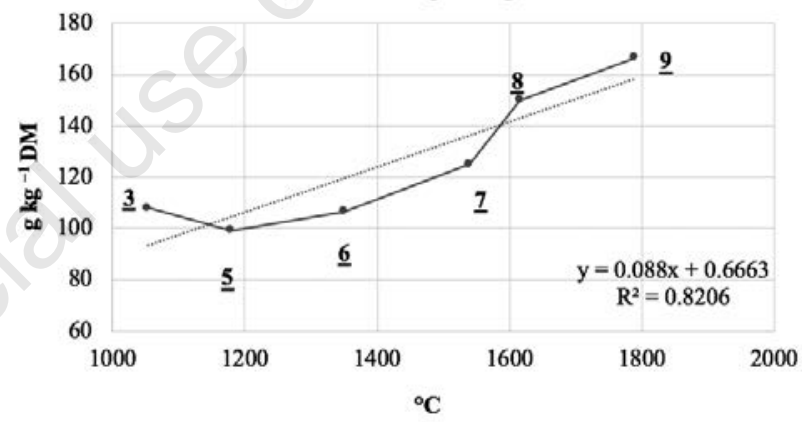

E) Ash

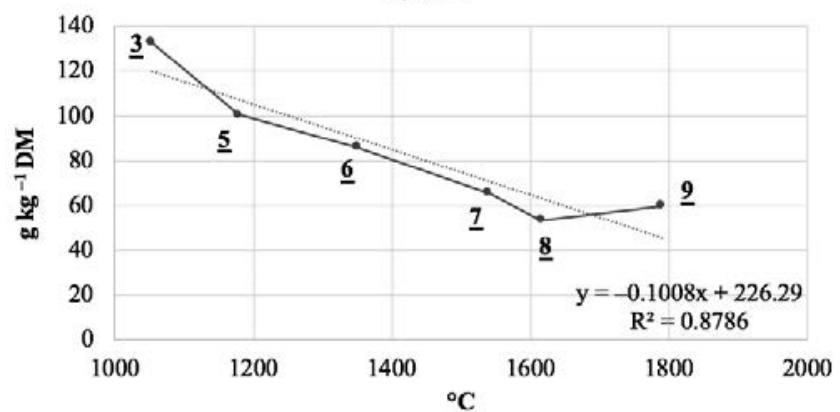

F) Ether extract

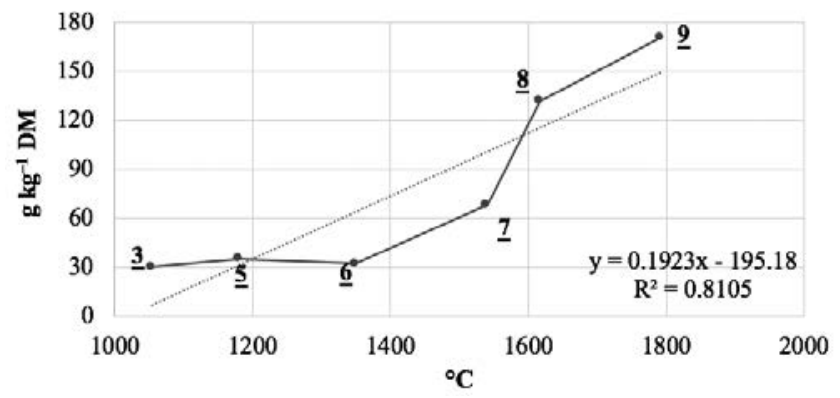

Figure 3. Bromatological composition of linseed shoot at six morphological stages: A) crude protein; B) neutral detergent fiber; C) acid detergent fiber; D) acid detergent lignin; E) ash; F) ether extract. Stages: 3: stem extension; 5: inflorescence emergence (main shoot); 6: flowering and capsule formation (whole plant); 7: development of seed and capsule; 8: capsule and seed ripening; 9: stem senescence. 
and fruits, regulating auxin transport, and protecting against pathogens, parasites, and predators (Winkel-Shirley, 2001).

Total phenolics, non-tannic phenolics, tannic phenolics (Figure 4) and total flavonoids (Figure 5) contents were negatively related with the morphological stages. Total phenolics, non-tannic phenolics, and tannic phenolics reached their highest values of 26.4, 16.4, $9.9 \mathrm{~g} \mathrm{GAE} \mathrm{kg}^{-1} \mathrm{DW}$, respectively, at stage 5 (inflorescence emergence - main stem) corresponding to 1200 GDD and their lowest value of 9.6, 7.4, $2.2 \mathrm{~g} \mathrm{GAE} \mathrm{kg}^{-1} \mathrm{DW}$, respectively, at stage 9 (stem senescence) after 1800 GDD. At the same GDD, total flavonoids decreased from 16.7 at stage 3 to $5.2 \mathrm{CE} \mathrm{kg}^{-1} \mathrm{DW}$ at stage 9. Re et al. (2013) reported a similar value (26.9 $\left.\mathrm{g} \mathrm{GAE} \mathrm{kg}^{-1}\right)$ of total phenolics for sainfoin (Onobrychis viciifolia Scop.) racemes at flowering. Additionally, a study on garland (Chrysanthemum coronarium L.) shoot harvested at flowering showed values of total phenolics, non-tannic phenolics, and total flavonoids of 28.9, $14.0 \mathrm{~g} \mathrm{GAE} \mathrm{kg}^{-1}$ and $21 \mathrm{~g} \mathrm{CE} \mathrm{kg}^{-1} \mathrm{DW}$, respectively (Sulas et al., 2017). With a different method for phytochemical extraction, Wang et al. (2017) reported for linseed sprouts values in total phenolics (an average of $2.05 \mathrm{~g} \mathrm{GAE}^{-1} \mathrm{~kg} \mathrm{DW}$ ) lower than our results, as well as, lower flavonoids contents $(1.6 \mathrm{~g} \mathrm{CE}$ $\mathrm{kg}^{-1} \mathrm{DW}$ ). El-Lethy et al. (2010) found in linseed plant harvested at vegetative stage, a total phenolics content of $1.81 \%$ and $1.64 \%$ in leaves treated using the antioxidants stigmasterol and putrescine, respectively, and of $0.88 \%$ in the control. Russo and Reggiani (2015), for different linseed varieties, reported much lower values for phenolic contents in seeds than those found in the present study for shoots harvested at vegetative stage. No condensed tannins were detected in linseed shoot under study.

As shown in Figure 6A, ABTS assay exhibited a decreasing variation of antioxidant capacity from about 16 (stem extension) to $9.3 \mathrm{mmol}$ TEAC/100 g DW (stem senescence). The total antioxidant capacity determined by the DPPH assay also decreased from 19 to $7 \mathrm{mmol} \mathrm{TEAC} / 100 \mathrm{~g} \mathrm{DW}$ at the same phenological stages, after 1050 and about 1800 GDD, respectively (Figure 6B). Our values of antioxidant activity were much higher than those obtained by Russo and Reggiani (2015), who performed the extraction using ethanol.

The correlations between the antioxidant activity revealed by the two assays (ABTS and DPPH), and TotP, NTP, TP, and TotF showed highly significant linear correlation (Table 2). Russo and Reggiani (2015) reported that the antioxidant capacity was significantly correlated with total polyphenolics in linseed varieties having different productive attitude (oil, fiber, intermediate). On the contrary, another study carried out by Souri et al. (2008), showed

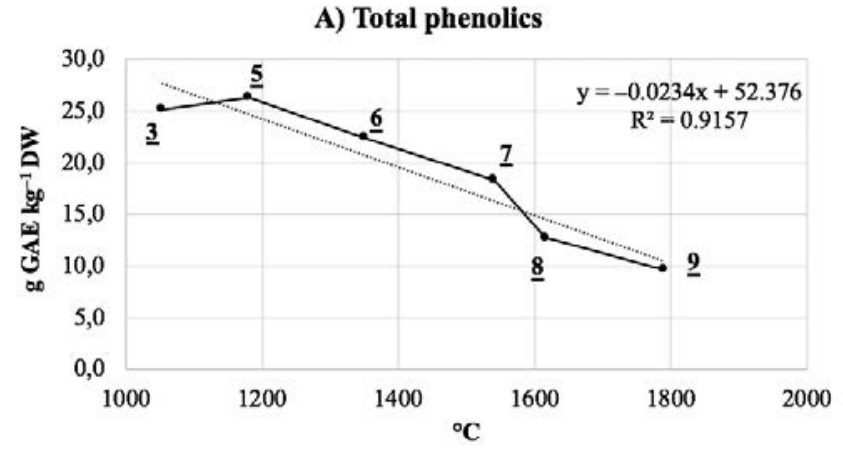

B) Non-tannic phenolics

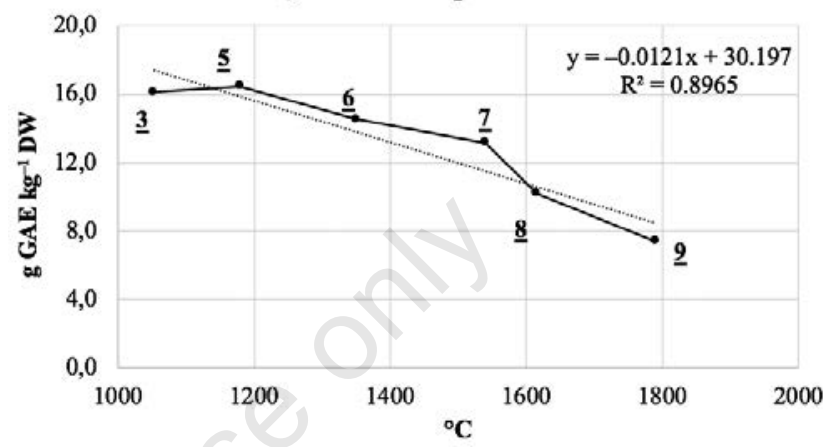

C) Tannic phenolics

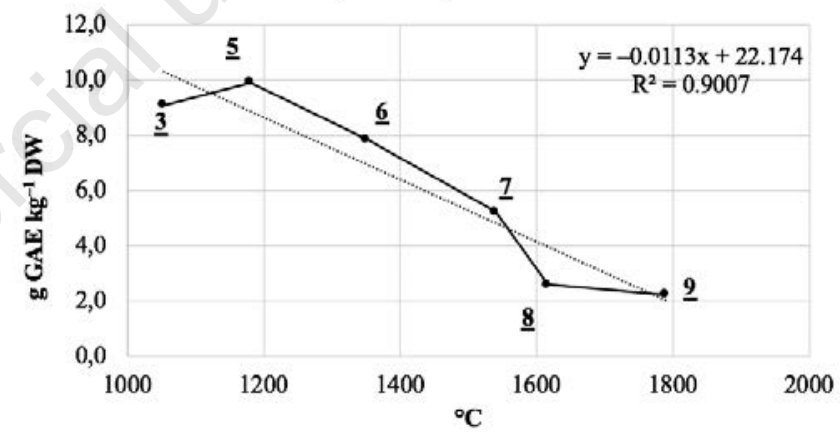

Figure 4. Bioactive compounds in linseed six morphological stages: A) total phenolics; B) non-tannic phenolics; C) tannic phenolics. Stages: 3: stem extension; 5: inflorescence emergence (main shoot); 6: flowering and capsule formation (whole plant); 7: development of seed and capsule; 8: capsule and seed ripening; 9: stem senescence.

Table 1. Total digestible nutrients, digestible dry matter, digestible dry matter intake, relative feed value and energy for lactation in relation to the morphological stages of linseed shoots.

\begin{tabular}{|c|c|c|c|c|c|c|}
\hline Morphological stages & Stage code & $\begin{array}{c}\text { TDN } \\
\left(\mathrm{g} \mathrm{kg}^{-1} \mathrm{DM}\right)\end{array}$ & $\begin{array}{c}\text { DDM } \\
\left(\mathrm{g} \mathrm{kg}^{-1} \mathrm{DM}\right)\end{array}$ & $\begin{array}{c}\text { DMI } \\
\text { ( } \mathrm{g} \mathrm{kg}^{-1} \mathrm{DM} \\
\text { of body weight) }\end{array}$ & $\begin{array}{l}\text { RFV } \\
(\%)\end{array}$ & $\begin{array}{c}\text { NEl } \\
\left(\text { Mcal kg-1) }^{-1}\right)\end{array}$ \\
\hline Stem extension & 3 & 593.0 & 886.5 & 25.2 & 173.2 & 1.45 \\
\hline Inflorescence emergence (main shoot) & 5 & 567.6 & 886.3 & 22.2 & 152.5 & 1.40 \\
\hline Flowering and capsule formation (whole plant) & 6 & 545.1 & 886.8 & 20.6 & 149.8 & 1.35 \\
\hline Development of seed and capsule (whole plant) & 7 & 454.7 & 885.6 & 21.1 & 144.9 & 1.17 \\
\hline Capsule and seed ripening & 8 & 433.5 & 885.5 & 19.6 & 134.5 & 1.12 \\
\hline Stem senescence & 9 & 417.4 & 885.8 & 18.4 & 126.3 & 1.09 \\
\hline$P \leq 0.05$ & & $* * *$ & $* * *$ & $* * *$ & $* * *$ & $* * *$ \\
\hline $\mathrm{R}^{2}$ & & 0.91 & 0.92 & 0.94 & 0.97 & 0.90 \\
\hline
\end{tabular}

TDN, total digestible nutrients; DDM, digestible dry matter; DMI, digestible dry matter intake; RFV, relative feed value; NEl, energy for lactation; DM, dry matter. 
no significant correlation between antioxidant activity and phenolics content of 24 medicinal plants, including seeds of linseed.

Highly significant linear correlations between the ABTS, DPPH and phenolics, as well as NDF, ADF, ADL, ash and ether extract were found (Table 3) except for ash and ABTS, NTP, TP. A highly significant correlation for NDF, ADF and antioxidant capacity and phenolics was reported by Sulas et al. (2016) in milk thistle (Silybum marianum (L.) Gaertn.). Conversely, Campion et al. (2013) found that cellulose accumulation is negatively correlated with total phenolic content in common bean (Phaseolus vulgaris L.) seeds.

The morphological stage was significantly correlated with shoot oil concentration $\left(\mathrm{R}^{2}=0.76\right)$ although fatty acid content (unsature, mono, and polyunsature) showed an irregular trend and did not correlate with morphological stage (Table 4). On the contrary, Peiretti and Maineri (2008) reported that chemical composition and FA profile of linseed is closely connected to the development of plant and both nutritional quality and PUFA content of linseed decreases.

Oil content ranged from 10.1 to $17.9 \%, \alpha$-linolenic acid from 33.5 to $40.6 \%$ and linoleic acid from 8.1 to $10.5 \%$. Myristic acid (C14:0) was present in small amounts in all the phenological stages. Peiretti and Meineri (2008) in a study about linseed fatty acid content in different phenological stages, reported results in agreement to our values for myristic (C14:0), stearic (C18:0), and $\alpha$-linolenic acid (C18:3). However, another study on the fatty acid profile for seed oil of flax reported a lower content of myristic, palmitic (C16:0), and palmitoleic acid (C16:1) than the present research, whereas the content of oleic (C18:1), linoleic (C18:2), and $\alpha$-linolenic acid (C18:3) were higher (Gutiérrez et al., 2010).

El-Lethy et al. (2010) found similar levels of LA but lower of ALA (5.5 and 12.2\%, respectively) in linseed grown in Egypt. In contrast with this study, Peiretti and Meineri (2008) found higher

Table 2. Correlation ( $R^{2}$ and equation) established between total phenolics, non-tannic phenolics, tannic phenolics, flavonoids and antioxidant capacity (ABTS, DPPH), in linseed shoots.

\begin{tabular}{lcccc}
\multicolumn{3}{c}{ ABTS } & \multicolumn{2}{c}{ DPPH } \\
TotP & $0.81^{*}$ & $\mathrm{y}=5.95+0.38 \mathrm{x}$ & $0.90^{* *}$ & $\mathrm{y}=1.89+0.61 \mathrm{x}$ \\
NTP & $0.97^{* *}$ & $\mathrm{y}=2.47+0.81 \mathrm{x}$ & $0.93^{* *}$ & $\mathrm{y}=-2.62+1.22 \mathrm{x}$ \\
\hline TP & $0.80^{*}$ & $\mathrm{y}=8.01+0.81 \mathrm{x}$ & $0.87^{* *}$ & $\mathrm{y}=5.32+1.30 \mathrm{x}$ \\
TotF & $0.91^{*}$ & $\mathrm{y}=0.91+0.59 \mathrm{x}$ & $0.97^{* *}$ & $\mathrm{y}=2.42+0.94 \mathrm{x}$ \\
\hline
\end{tabular}

ABTS, 2,2'-azinobis (3-ethylbenzothiazoline-6-sulphonic acid) diammonium salt; DPPH, 1,1-diphenyl-2picrylhydrazyl; TotP, total phenolics; NTP, non-tannic phenolics; TP, tannic phenolics; TotF, flavonoids. *Significance level at $\mathrm{P} \leq 0.05 ;{ }^{* *}$ Significance level at $\mathrm{P} \leq 0.001$.

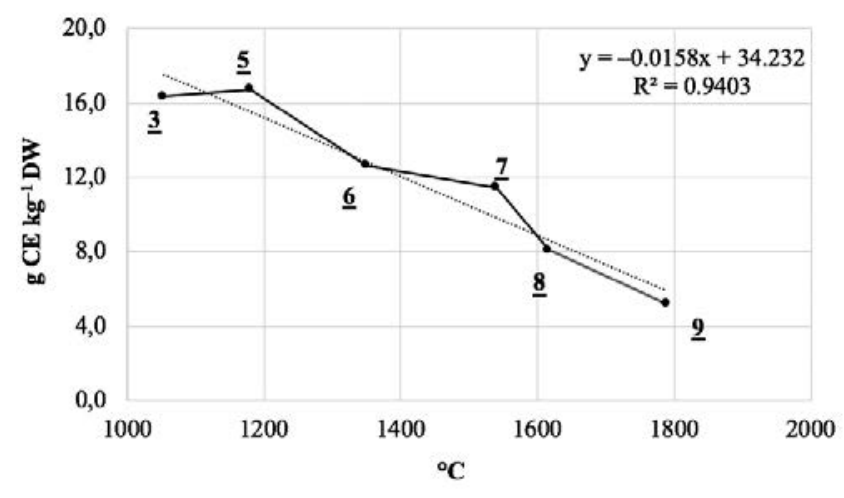

Figure 5. Total flavonoids content in linseed shoots six morphological stages. Stages: 3: stem extension; 5: inflorescence emergence (main shoot); 6: flowering and capsule formation (whole plant); 7: development of seed and capsule; 8: capsule and seed ripening; 9: stem senescence.
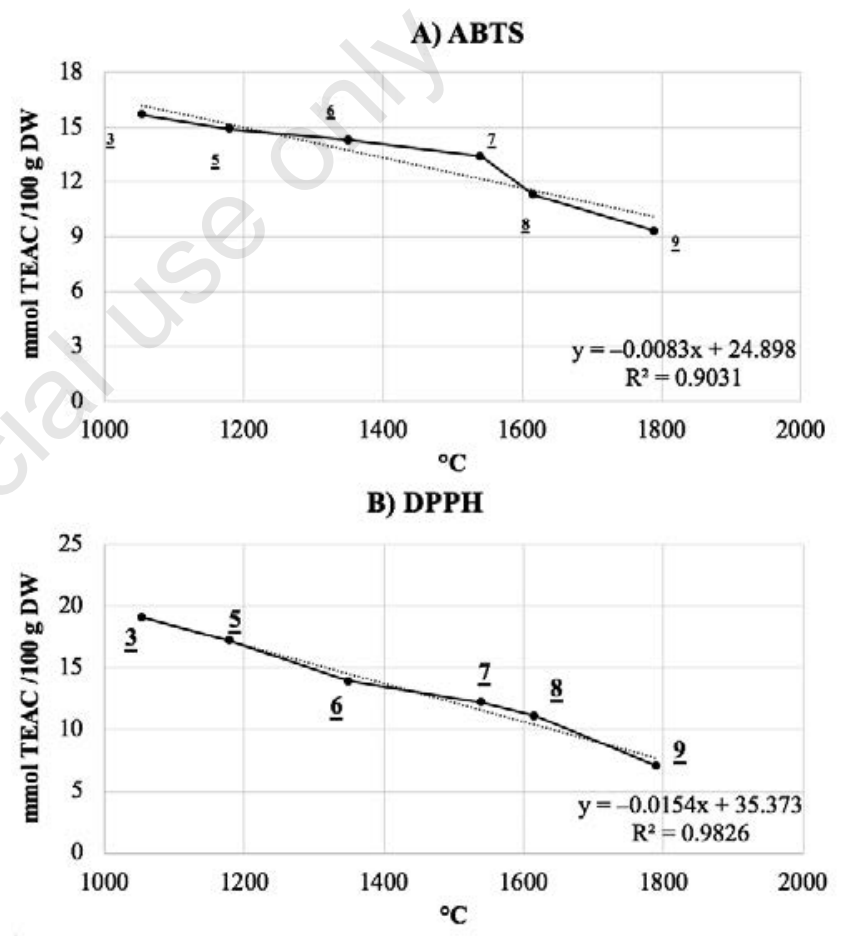

Figure 6. Antioxidant activity in linseed shoots six morphological stages: A) ABTS method; B) DPPH method. Stages: 3: stem extension; 5: inflorescence emergence (main shoot); 6: flowering and capsule formation (whole plant); 7 : development of seed and capsule; 8: capsule and seed ripening; 9: stem senescence.

Table 3. Correlation ( $\mathrm{R}^{2}$ and equation) established between antioxidant capacity (ABTS, DPPH), total phenolics, non-tannic phenolics, tannic phenolics, flavonoids and quality features, in linseed shoots.

\begin{tabular}{|c|c|c|c|c|c|c|c|c|c|c|c|}
\hline \multicolumn{3}{|r|}{ ABTS } & \multicolumn{2}{|c|}{ DPPH } & \multicolumn{2}{|c|}{ TotP } & \multicolumn{2}{|c|}{ NTP } & \multicolumn{2}{|c|}{ TP } & TotF \\
\hline $\mathrm{CP}$ & $0.67 *$ & $y=0.41+0.11 x$ & $0.86 * *$ & $y=-8.63+0.17 x$ & $0.81^{*}$ & $y=-14.0+0.28 x$ & $0.72 *$ & $y=-2.96+0.14 x$ & $0.74 *$ & $y=-8.55+0.12 x$ & $0.78 * \quad y=-10.5-$ \\
\hline NDF & $0.91^{* *}$ & $\mathrm{y}=54.2-0.07 \mathrm{x}$ & $0.91^{* *}$ & $\mathrm{y}=76.7-0.11 \mathrm{x}$ & $0.79^{*}$ & $y=100.2-0.16 x$ & $0.89 * *$ & $\mathrm{y}=63.0-0.09 \mathrm{x}$ & $0.76^{*}$ & $y=49.9-0.07 x$ & $0.88^{* *} \quad \mathrm{y}=77.4-0.11 \mathrm{x}$ \\
\hline ADF & $0.76^{*}$ & $\mathrm{y}=35.5$ & $0.84^{*}$ & $\mathrm{y}=49.8$ & $0.84^{*}$ & $y=74.9-0.14 x$ & $0.80 *$ & $y=41.4-0.07 x$ & $0.81^{*}$ & $y=31.9-0.07 x$ & $0.82^{*}$ \\
\hline ADL & $0.89 * *$ & $y=26.3-0.11 x$ & $0.90 * *$ & $y=33.5-0.16 x$ & $0.91^{* *}$ & $y=50.4-0.26 x$ & $0.95^{* *}$ & $y=29.9-0.13 x$ & $0.96 * *$ & $y=21.4-0.12 x$ & $0.93^{* *} \quad y=33.7-0.18 x$ \\
\hline Ash & $0.64 \mathrm{~ns}$ & $y=6.13+0.08 x$ & $0.83^{*}$ & $y=1.21-0.14 x$ & $0.67^{*}$ & $\mathrm{y}=1.73-0.20 \mathrm{x}$ & $0.64 \mathrm{~ns}$ & $\mathrm{y}=4.58-0.10 \mathrm{x}$ & $0.56 \mathrm{~ns}$ & $y=-1.02-0.08 x$ & $y=-0.12-0.14 x$ \\
\hline $\mathrm{EE}$ & $0.94^{* *}$ & $y=16.8-0.05 x$ & $0.85^{* *}$ & $y=18.8-0.07 x$ & $0.84^{* *}$ & $y=27.0-0.11 x$ & $0.95^{* *}$ & $y=17.7-0.06 x$ & $0.88^{* *}$ & $y=10.2-0.05 x$ & $0.90^{* *} \quad \mathrm{y}=17.6-0.08 \mathrm{x}$ \\
\hline
\end{tabular}

ABTS, 2,2'-azinobis (3-ethylbenzothiazoline-6-sulphonic acid) diammonium salt; DPPH, 1,1-diphenyl-2-picrylhydrazyl; TotP, total phenolics; NTP, non-tannic phenolics; TP, tannic phenolics; TotF, flavonoids; CP, crude protein; NDF, neutral detergent fiber; ADF, acid detergent fiber; ADL, acid detergent lignin; EE, ether extract. *Significance level at $\mathrm{P} \leq 0.05 ;{ }^{* *}$ Significance level at $\mathrm{P} \leq 0.001$; ns, not significant. 
Table 4. Fatty acid composition (\%) in relation to the morphological stages of linseed shoots.

\begin{tabular}{|c|c|c|c|c|c|c|c|c|c|c|}
\hline $\begin{array}{l}\text { Morphological } \\
\text { stages }\end{array}$ & $\begin{array}{l}\text { Stage } \\
\text { code }\end{array}$ & $\begin{array}{c}\text { Myristic } \\
\text { acid } \\
\text { (C14:0) } \\
(\%)\end{array}$ & $\begin{array}{c}\text { Palmitic } \\
\text { acid } \\
(\mathrm{Cl6:0}) \\
(\%)\end{array}$ & $\begin{array}{c}\text { Stearic } \\
\text { acid } \\
\text { (C18:0) } \\
(\%)\end{array}$ & $\begin{array}{l}\text { Arachidic } \\
\text { acid } \\
(\mathrm{C} 20: 0) \\
(\%)\end{array}$ & $\begin{array}{l}\text { Palmitoleic } \\
\text { acid } \\
\text { (C16:1) } \\
(\%)\end{array}$ & $\begin{array}{c}\text { Oleic } \\
\text { acid } \\
\text { (C18:1) } \\
(\%)\end{array}$ & $\begin{array}{l}\text { Linoleic } \\
\text { acid } \\
\text { (C18:2) } \\
(\%)\end{array}$ & $\begin{array}{c}\alpha \text {-linolenic } \\
\text { acid } \\
(\mathrm{C18:3)} \\
(\%)\end{array}$ & $\begin{array}{c}\text { Oil } \\
\text { content } \\
(\%)\end{array}$ \\
\hline Stem extension & 3 & $<0.1$ & 15.1 & 5.8 & 11.3 & 1.7 & 9.1 & 8.9 & 35.6 & 11.8 \\
\hline $\begin{array}{l}\text { Inflorescence emergence } \\
\text { (main shoot) }\end{array}$ & 5 & $<0.1$ & 15.1 & 10.6 & 10.3 & 2.4 & 6.2 & 9.4 & 40.6 & 10.1 \\
\hline $\begin{array}{l}\text { Flowering and capsule formation } \\
\text { (whole plant) }\end{array}$ & 6 & $<0.1$ & 12.9 & 5.5 & 12.5 & 3.1 & 9.6 & 8.1 & 33.5 & 13.7 \\
\hline $\begin{array}{l}\text { Development of seed and capsule } \\
\text { (whole plant) }\end{array}$ & 7 & $<0.1$ & 16.8 & 6.5 & 13.1 & 2.0 & 7.3 & 8.7 & 35.2 & 14.1 \\
\hline Capsule and seed ripening & 8 & $<0.1$ & 15.8 & 11.7 & 8.9 & 2.4 & 6.2 & 10.5 & 38.7 & 16.4 \\
\hline Stem senescence & 9 & $<0.1$ & 15.9 & 7.8 & 12.1 & 2.2 & 5.0 & 9.8 & 35.4 & 17.9 \\
\hline$P \leq 0.05$ & & ns & ns & ns & ns & ns & ns & ns & ns & $* * *$ \\
\hline $\mathrm{R}^{2}$ & & - & 0.27 & 0.25 & $2.5 \times 10-4$ & 0.06 & 0.30 & 0.43 & 0.35 & 0.76 \\
\hline
\end{tabular}

values for both fatty acids and evidenced that LA and ALA were affected by phenological stages of linseed, presumably influenced by the different sowing time (late autumn in Sardinia and June in Piedmont, respectively) and environmental conditions. In galega (Galega officinalis L.) and quinoa (Chenopodium quinoa Willd.), Peiretti and Gai (2006) and Peiretti et al. (2013) found similar and higher concentration of linoleic acid compare to linseed, whereas $\alpha$-linolenic acid had an opposite trend.

\section{Conclusions}

The quality traits of green linseed grown in a Mediterranean environment elucidated in the present study supply additional information regarding the entire range of utilisation of such crop, as linseed is usually considered as a dual purpose crop (fiber and seed). The evolution of bromatological composition, fatty acid content, bioactive compounds and antioxidant capacity of linseed shoots at six different codified morphological stages, was closely related to the plant development, indicating a decrease of shoot quality from the first to the last morphological stage.

Therefore, our results suggest harvesting/utilising linseed shoots before stage 6 (flowering and capsule formation). Moreover, our research evidenced that aerial biomass of linseed represent, (particularly at early stage) a valuable source of phenolic antioxidants, with potential benefits for animal welfare and as an alternative to synthetic antioxidants.

A further achievement is an increased awareness about the evolution of fatty acid content that resulted little influenced by the morphological stages, with implications for a whole exploitation of green linseed as a forage source. Future studies require elucidation of the chemical composition of phenolics in relation to the potential development of new natural antioxidant for natural health care of animals.

\section{References}

Bhatty RS, Cherdkiatgumchai P, 1990. Compositional analysis of laboratory-prepared and commercial samples of linseed meal and of hull isolated from flax. J. Am. Oil. Chem. Soc. 67:79-84.

Borreani G, Ciotti A, Peiretti PG, Re GA, Roggero PP, Sargenti P, Sulas L, Valente ME, 1999. Relazioni tra stadio morfologico di sviluppo, produttività e qualità del foraggio della sulla in due ambienti collinari. Ital. J. Agr. 33:170-6.

Brglez Mojzer E, Knez Hrnčič M, Škerget M, Knez Ž, Bren U, 2016. Polyphenols: extraction methods, antioxidative action, bioavailability and anticarcinogenic effects. Molecules 21:901. Cabiddu A, Addis M, Fiori M, Spada S, Decandia M, Molle G. (2017). Pros and cons of the supplementation with oilseed enriched concentrates on milk fatty acid profile of dairy sheep grazing Mediterranean pastures. Small Rumin Res. 147:63-72.

Campion B, Glahn RP, Tava A, Perrone D, Doria E, Sparvoli F, Cecotti R, Dani V, Nielsen E, 2013. Genetic reduction of antinutrients in common bean (Phaseolus vulgaris L.) seed, increases nutrients and in vitro iron bioavailability without depressing main agronomic traits. Field Crops. Res. 141:27-37.

Cappa C, Lucisano M, Mariotti M, 2013. Rheological and properties of gels obtained from the gluten-free raw material during a short-term aging. LWT - Food Sci. Technol. 53:464-72.

Chilliard Y, Ferlay A, Mansbridge RM, Doreau M, 2000. Ruminant milk fat plasticity: nutritional control of saturated, polyunsaturated, trans and conjugated fatty acids. Ann. Zootec. 49:181-205.

Chilliard Y, Glasser F, Ferlay A, Bernard L, Rouel J, Doreau, M, 2007. Diet, rumen biohydrogenation and nutritional quality of cow and goat milk fat. Eur. J. Lipid Sci. Tech. 109:828-55.

Cloutier S, Ragupathy R, Niu Z, Dugiud S, 2011. SSR-based linkage map of flax (Linum usitatissimum L.) and mapping of QTLs underlying fatty acid composition traits. Mol. Breed. 28:437-51.

Correddu F, Nudda A, Battacone G, Boe R, Francesconi AHD, Pulina G, 2015. Effects of grape seed supplementation, alone or associated with linseed, on ruminal metabolism in Sarda dairy sheep. Anim. Feed. Sci. Technol. 199:61-72.

de Moura CM, Ad Júnior MSS, Fiorda FA, Caliari M, Vera R, Grossmann MVE, 2016. Cooking and texture properties of gluten-free fettuccine processed from defatted flaxseed flour and rice flour. Int. J. Food. Sci. Tech. 51:1495-501.

Diederichsen A, Ulrich A, 2009. Variability in stem fibre content and its association with other characteristics in 1177 flax (Linum usitatissimum L.) genebank accessions. Ind. Crops Prod. 30:33-9. 
Duguid SD, 2009. "Flax". In: Vollmann J. and Rajcan I. (Eds.), Oil crops. Series: Handbook of plant breeding. Vol. 4, Springer New York, Chapter 7, pp. 233-256.

Eyres L, Eyres M, 2014. Flaxseed (Linseed) fibre - nutritional and culinary uses - a review. Food N. Zeal. 14:2.

Feist M, 2007. Saskatchewan agriculture and food. Available from: http://www.agriculture.gov.sk.ca/Default

Fofana B, Cloutier S, Duguid S, Ching J, Rampitesch C, 2006. Gene expression of stearoyl-ACP desaturase and delta12 fatty acid desaturase 2 in modulated during seed development of flax (Linum usitatissimum L.). Lipids 41:705-20.

Fontana F, Fila G, Maestrini C, Govoni F, 1998. Lino da fibra: aspetti bioagronomici e produttivi. Inf. Agrar. 11:55-9.

Gutiérrez C, Rubilar M, Jara C, Verdugo M, Sineiro J, Shene C, 2010. Flaxseed and flaxseed cake as a source of compounds for food industry. J. Soil Sci. Plant. Nutr. 10:454-63.

Häring DA, Suter D, Amrhein N, Lüscher A, 2007. Biomass allocation is an important determinant of the tannin concentration in growing plants. Ann. Bot. 99:111-20.

Heuzé V, Tran G, Lebas F, 2015. Flax straw and flax crop by-products. Feedipedia, a programme by INRA, CIRAD, AFZ and FAO. Available from: http://www.feedipedia.org/node/132

Horrocks RD, Vallentine JF, 1999. Harvested forages. London, UK: Academic Press.

Jankauskiené Z, Grudeviené E, 2015. Recent results of flax breeding in Lithuania. Ind. Crops Prod. 75:185-94.

Kajla P, Sharma A, Sood DR, 2015. Flaxseed - a potential food source. J. Food Sci. Technol. 52:1857-71.

Kalu BA, Fick GW, 1981. Quantifying morphological development of alfalfa for studies of herbage quality. Crop Sci. 21:267-71.

Kasote DM, 2013. Flaxseed phenolics as natural antioxidant. Int. Food Res. J. 20:27-34.

Komlajeva L, Adamovics A, 2012. Evaluation of flax (Linum usitatissimum L.), quality parameters for bioenergy production. Proc. $11^{\text {th }}$ International Scientific Conference Engineering for Rural Development, 24-25 May 2012, Jelgava, Latvia, 11:490-496.

Korus J., Witczak T., Ziobro R., Juszczak L, 2015. Linseed (Linum usitatissimum L.,) mucilage as novel structure forming agent in gluten-free bread. LWT Food Sci. Technol. 62:257-64.

Lithourgidis, AS, Vasilakoglou IB, Dhima KV, Dordas CA, Yiakoulaki MD, 2006. Forage yield of common vetch mixtures with oat and triticale in two seeding ratios. Field Crop Res. 99:106-13.

Liu RH, 2007. Whole grain phytochemicals and health. J. Cereal. Sci. 46:207-19.

Lourenço M, Ramos-Morales E, Wallance RJ, 2010. Ruminal biohydrogenation in Holstein cows fed soybean fatty acid as amides or calcium salts. J. Dairy Sci. 87:1038-46.

Mele M, 2009. Designing milk fat to improve healthfulness and functional properties of dairy products: from feeding strategies to a genetic approach. Ital. J. Anim. Sci. 8:365-74.

Mele M, Contarini G, Cercaci L, Serra A, Buccioni A, Povolo M, Conte G, Funaro A, Banni S, Lercker G, Secchiari P, 2011. Enrichment of Pecorino cheese with conjugated linoleic acid by feeding dairy ewes with extruded linseed: effect on fatty acid and triglycerides composition and on oxidative stability. Int. Dairy J. 21:365-72.

Miller P, Lanier W, Brandt S, 2001. Using growing degree days to predict plant stages. Montana State University Extension Service. MontGuide fact sheet MT200103 AG 7/2001. Data source: Stu Brandt, Scott, SK 1993-97 and Perry Miller, Swift Current, SK 1995-98.
Mirshekari M, Amiri R, Nezhad HI, Sadat Noori SA, Zandvakili R, 2012. Effects of planting date and low irrigation on quantitative and qualitative traits of flax seed. Am.-Eur. J. Agric. Environ. Sci. 12:901-13.

Nackz M, Shahidi F, 2004. Extraction and analysis of phenolics in food. J. Chromatogr. A. 1054:95-111.

Nudda A, Battacone G, Usai MG, Pulina G, 2006. Supplementation with extruded linseed cake affects concentrations of conjugated linolic acid and vaccenic acid in goat milk. J. Dairy Sci. 80:277-82.

Oomah BD, 2001. Flaxseed as a functional food source. J. Sci. Food Agric. 81:889-94.

Pandey KB, Rizvi SI, 2009. Plant polyphenols as dietary antioxidants in human health and disease. Oxid. Med. Cell. Longev. 2:270-8.

Peiretti PG, Gai F, 2006. Chemical composition, nutritive value, fatty acid and amino acid content of Galega officinalis L. during its growth stage and in regrowth. Anim. Feed Sci. Technol. 130:257-67.

Peiretti PG, Gai F, Tassone S, 2013. Fatty acid profile and nutritive value of quinoa (Chenopodium quinoa Willd.) seeds and plants at different growth stages. Anim. Feed Sci. Technol. 183:56-61.

Peiretti PG, Meineri G, 2006. Fatty acids, chemical composition and organic matter digestibility of seeds and vegetative parts of false flax (Camelina sativa L.) after different lengths of growth. Anim. Feed Sci. Technol. 133:341-50.

Peiretti PG, Meineri G, 2008. Chemical composition, organic matter digestibility and fatty acid content of linseed (Linum usitatissimum L.) harvested at five stages of growth. J. Sci. Food. Agric. 88:1850-4.

Peiretti PG, Palmegiano GB and Salamano G, 2004. Quality and fatty acid content of borage (Borago officinalis L.) during the growth cycle. Ital. J. Food Sci. 2:177-84.

Piluzza G, Bullitta S, 2010. The dynamics of phenolics concentration in some pasture species and implications for animal husbandry, J. Sci. Food Agric. 90:1452-9.

Piluzza G, Bullitta S, 2011. Correlations between phenolic content and antioxidant properties in twenty-four plant species of traditional ethnoveterinary use in the Mediterranean area. Pharm. Biol. 49:240-7.

Piluzza G, Sulas L, Bullitta S, 2014a. Tannins in forage plants and their role in animal husbandry and environmental sustainability: a review. Grass Forage Sci. 69:32-48.

Piluzza G, Sulas L, Bullitta S, 2014b. Dry matter yield, feeding value, and antioxidant activity in Mediterranean chicory (Cichorium intybus L.) germplasm. Turk. J. Agric. For. 38:506-14.

Pintus S, Murru E, Carta G, Cordeddu L, Batetta B, Accossu S, Pistis D, Uda S, Ghiani ME, Mele M, Secchiari P, Almeringhi G, Banni S, 2013. Sheep cheese naturally $\alpha$-linolenic, conjugated linoleic and vaccenic acids improves the lipid profile and reduces anandamide in the plasma of hypercholesterolaemic subjects. Br. J. Nut. 109:1453-62.

Popa VM, Gruia A, Raba DN, Dumbrava D, Moldovan C, Bordean D, Mateescu C, 2012. Fatty acid composition and oil characteristics of linseed (Linum usitatissimum L.) from Romania. J. Agroaliment. Proc. Technol. 18:136-40.

Re GA, Piluzza G, Sulas L, Franca L, Porqueddu C, Sanna F, Bullitta S, 2013. Condensed tannin accumulation and nitrogen fixation potential of Onobrychis viciifolia Scop. grown in a Mediterranean environment. J. Sci. Food Agric. 94:601-18.

Roukos CN, Kyriazopoulos AP, Abraham EM, Parissi ZM, Karatassiou M, 2017. Nutritional quality of herbaceous vege- 
tation in Phryganic Mediterranean ecosystem during the grazing period. Not. Bot. Horti. Agrob. Cluj-Napoca 45:149-56.

Rowland GG, 1998. Growing flax: production, management and diagnostic guide. Flax Council of Canada and Saskatchewan Flax Development Commission, Saskatoon, Canada.

Russo R, Reggiani R, 2015. Phenolics and antioxidant activity in flax varieties with different productive attitude. Int. Food Res. J 22:1736-9.

Treml J, Šmejkal K, 2016. Flavonoids as potent scavengers of hydroxyl radicals. Comprehensive reviews in Food Sci. Food Saf. 15:720-38.

Saastamoinen M, Pihlava JM, Eurola M, Klemola A, Jauhiainen L, Hietaniemi V, 2013. Yield, SDG lignan, cadmium, lead, oil and protein contents of linseed (Linum usitatissimum L.) cultivated in trials and at different farm conditions in the southwestern part of Finland. Agric. Food Sci. 22:296-306.

Sadeghpour A, Jahnzad E, Lithourgidis AS, Hasmen M, MB Hosseini, 2014. Forage yield and quality of barley-annual medic intercrops in semi-arid environments. Int. J. Plant Prod. 8:77-90.

Santurino C, Calvo MV, Gomez-Candela C, Fontecha J. 2017. Characterisation of naturally goat cheese enriched in conjugated linoleic acid and omega-3 fatty acids for human clinical trial in overweight and obese subjects. Pharm. Nutr. 5:8-17.

Sejian V, Laktriz J, Ezeji T, Lal R, 2010. Forage and flax seed impact on enteric methane emission in dairy cows. Res. J. Vet. Sci. 4:1-8.

Singh KK, Mridula D, Banwal P, Rehal J, 2013. Selected engineering and biochemical properties of 11 flaxseed varieties. Food Bioproc. Tech. 6:598-605.

Smith MJ, Froment MA, 1998. A growth stage key for winter linseed (Linum usitatissimum L.). Ann. Appl. Biol. 133:297-306.

Soto-Cerda BJ, Duguid S, Bokker H, Rowland G, Diederichsen A, Cloutier S, 2014. Association mapping of seed quality traits using the Canadian flax (Linum usitatissimum L.) core collection. Theor. Appl. Genet. 127:881-96.

Souri E, Amin G, Farsam H, 2008. Screening of antioxidant activity and phenolic content of 24 medicinal plant extracts. DARU J. Pharm. Sci. 16:83-7.

StatPoint Technologies Inc., 2009. Statgraphics Centurion XVI
User Manual. Virginia, USA.

Sulas L, Petretto GL, Pintore G, Piluzza G, 2017. Bioactive compounds and antioxidants from a Mediterranean garland harvested at two stages of maturity. Nat. Prod. Res. 31:2941-4.

Sulas L, Re GA, Bullitta S, Piluzza G, 2016. Chemical and productive properties of two Sardinian milk thistle (Silybum marianum (L.) Gaertn.) populations as sources of nutrients and antioxidants. Genet. Resour Crop Evol. 63:315-26.

Surveswaran S, Cai Y, Corke H, Sun M, 2007. Systematic evaluation of natural phenolic antioxidant from 133 Indian medicinal plants. Food Chem. 102:938-53.

Tavarini S, Angelini LG, Casadei N, Spugnoli P, Lazzeri L, 2016. Agronomical evaluation and chemical characterisation of Linum usitatissimum L. as oilseed crop for bio-based products in two environments of Central and Northern Italy. Ital. J. Agr. 11:122-32.

Van Soest PJ, 1994. The Nutritional Ecology of the Ruminant ( $2^{\text {nd }}$ ed.), Cornell University Press, Ithaca, NY, USA.

Wang H, Wang J, Qiu C, Ye C, Guo X, Chen G, Li T, Wang Y, Fu X, Liu RH, 2017. Comparison of phytochemical profiles and health benefits in fiber and oil flaxseeds (Linum usitatissimum L.). Food Chem. 214:227-3.

Winkel-Shirley B, 2001. Flavonoid biosynthesis. A colorful model for genetics, biochemistry, cell biology, and biotechnology. Plant Physiol. 126:485-93.

Zhang T, Lamb EG, Soto-Cerda B, Duguid S, Cloutier S, Rowland G, Dierderichsen A, Booker HM, 2014. Structural equation modeling of the Canadian flax (Linum usitatissimum L.) core collection for multiple phenotypic traits. Can. J. Plant Sci. 94:1325-32.

Zohary D, 1999. Monophyletic vs. polyphyletic origin of the crops on which agriculture was founded in the Near East. Genet. Resour. Crop Evol. 46:133-42.

Zuk M, Richter D, Matula J, Szopa J, 2015. Linseed, the multipurpose plant. Ind. Crops Prod. 75:165-77. 